\title{
Ruling makes it harder to convict dig thieves
}

Rex Dalton, San Diego

Archaeological sites across the United States are under increased threat from looters and vandals, according to researchers in the field. They argue that a ruling last December by a Californian court has made it harder to secure convictions under the federal Archeological Resources Protection Act (ARPA).

The ruling raised the burden of proof for prosecutors, requiring them to prove that a defendant knew that a looted specimen was an archaeological resource. Archaeologists fear that this decision will limit prosecutions under ARPA, which was enacted in 1979 to help save cultural artefacts situated on federalland.

As if to confirm these worries, a federal prosecutor in Colorado last month declined to use ARPA to indict a couple alleged to have removed Native American skeletal remains from a lake bed in the San Juan National Forest near Dolores, Colorado. The assistant US attorney in Durango, Robert Kennedy, blamed the court ruling as the reason for not proceeding with felony indictments. The case remains under investigation, but some federal authorities fear that there will be no prosecution. Kennedy declined to be interviewed.

Archaeologist Mark Varien, research director at the Crow Canyon Archaeology Center in Cortez, Colorado, described the failure to prosecute as "the height of absurdity", as it is widely known in the region that it is illegal to take archaeological artefacts. "This gives a green light to those who want to loot," says Varien, "and it fails to educate the public about damaging these dwindling resources."

At the annual meeting of the Society for American Archaeology (SAA) in New Orleans this spring, researchers and lawenforcement officers held a symposium on ARPA's role. From 1906 until 1979, authorities say there were only 18 criminal convictions for archaeology crimes on federal lands under a previous law. But during the past 10 years, there have been at least 37 convictions under ARPA, including several in which commercial looters were imprisoned for years.

"The ARPA statute has not solved the archaeological-resources crime problem, but it has had a significant impact on the activities of looters and vandals," says Martin McAllister, a former US Forest Service archaeologist who now is a Montana consultant on archaeology crimes.

But the case of Ian Lynch, who has been charged under ARPA for removing a 1,400year-old skull from Heceta Island, Alaska, could undermine the law's track record. The US Court of Appeals for the Ninth Circuit

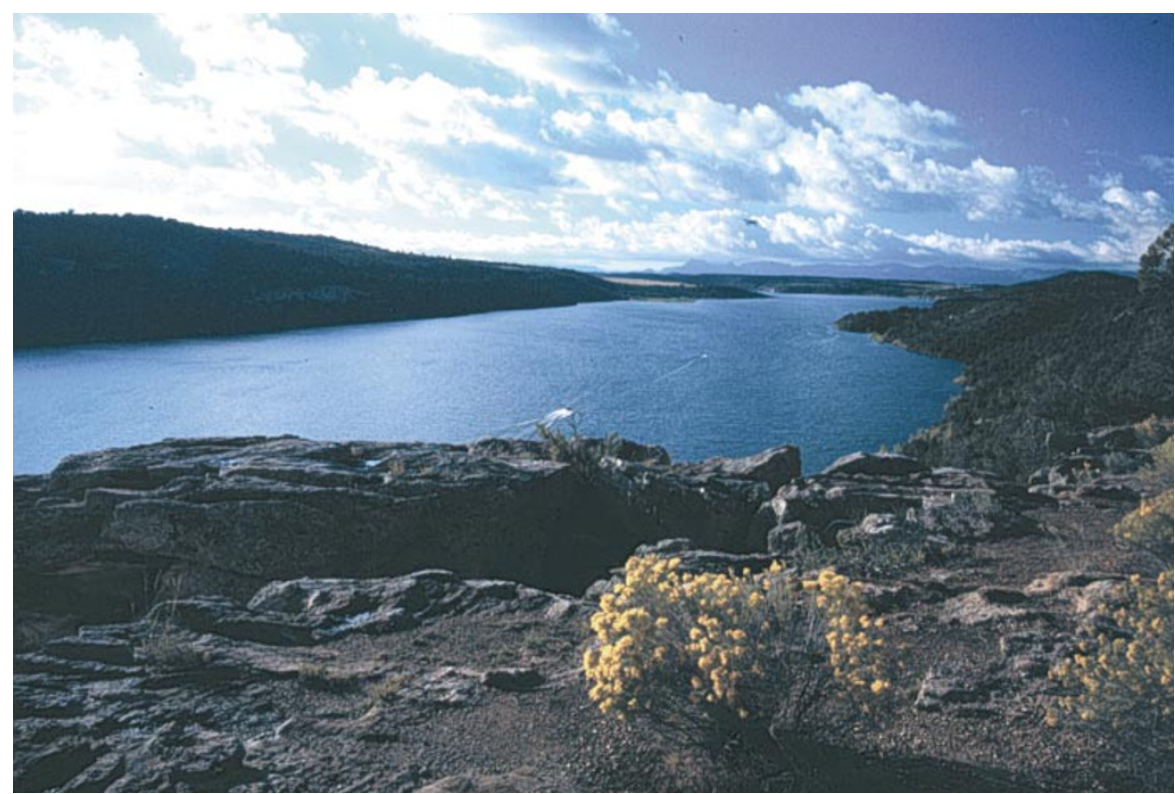

Hunting ground: McPhee Reservoir in Colorado is a favourite target of archaeological looters.

in San Francisco ruled last December that prosecutors must prove that Lynch knew the skull was an archaeological resource. It is this standard of proof that has upset archaeologists and law-enforcement personnel.

Wayne Dance, an assistant US attorney in Salt Lake City who has prosecuted some of the nation's most celebrated archaeological cases, called the Lynch decision "fundamentally flawed". As a result of the decision, Dance says, prosecutors will have "to prove that the defendant knew that his or her conduct affected an archaeological resource, regardless of the otherwise wrongful nature of that conduct".

Privately, a federal prosecutor in another southwestern state said that the government may now need either a confession or direct evidence - such as a tape recording or writing - of a defendant's knowledge that the objects in question are an archaeological resource.

But Steven Skrocki, the Assistant US Attorney in Anchorage, Alaska, who is prosecuting the Lynch case, believes that he will still win a conviction of the defendant, who now is pleading innocent for a trial set for later this year.

\section{Deputies caught on the wrong side of the law}

Looters of archaeological sites in the United States are often petty criminals with a history of convictions for theft and other offences. But an Arizona case has exposed a different breed of 'pot-hunters': a couple of sheriff's deputies, one of whom learned archaeology from a government scientist.

The two Yavapai County deputies lost their jobs after pleading guilty last month to a felony charge of looting an archaeological resource.

Tony Mascher and John Price will be sentenced next month in the US District Court in Phoenix for violating the Archaeological Resources Protection Act at the
Kinnikinick site in the Coconino National Forest. They face possible prison sentences.

As a high-school student, Mascher opted to study archaeology under a Forest Service archaeologist in the Tonto National Forest, northeast of Phoenix. Federal authorities believe he used this knowledge for his later criminal behaviour.

After searches of Mascher's home a year ago, authorities found an extensive collection of "museum-quality" Native American artefacts. All were seized by federal agents. However, most are expected to be returned to Mascher, as he has told authorities that they were legally obtained from private land.

The sheriff's deputies were caught when an Arizona State University archaeology graduate student, Wesley Bernardini, discovered them digging at the isolated Kinnikinick site. Using their legal knowledge, the deputies delayed a search of their camp-site and vehicles until late at night. The authorities believe this allowed them to throw away incriminating artefacts. When federal agents finally examined the camp-site, they found it surrounded by discarded pieces of pottery, some of which matched freshly excavated artefacts from Kinnikinick. 